\title{
APLIKASI GEOSPASIAL MENGGUNAKAN ARCGIS 10.3 DALAM PEMBUATAN PETA DAYA HANTAR LISTRIK DI CEKUNGAN AIRTANAH SUMOWONO
}

\author{
Thomas Triadi Putranto \& Kevin Alexander
}

\author{
Departemen Teknik Geologi, Fakultas Teknik, Universitas Diponegoro \\ JI. Prof. H. Soedarto, S.H. Tembalang-Semarang, Kode Pos 50275 \\ Telp/Fax : (024) 76480787 \\ e-mail: putranto@ft.undip.ac.id
}

\begin{abstract}
ABSTRAK
Air tanah sebagai air bersih merupakan salah satu kebutuhan primer manusia yang dimanfaatkan dalam berbagai kepentingan manusia serta untuk air minum. Airtanah memiliki kualitas dimana salah satu parameter fisiknya adalah daya hantar listrik (DHL). Dalam suatu Cekungan Airtanah (CAT), airtanah memiliki keberagaman nilai daya hantar listrik yang dipengaruhi oleh faktor infiltrasi dan lingkungan. Nilai DHL dapat dijadikan suatu acuan mengenai kelayakan suatu airtanah sebagai air minum. Sebagai salah satu sumber yang paling diminati masyarakat, maka masyarakat juga perlu untuk mengetahui kualitas dari airtanah tersebut melalui parameter daya hantar listrik sehingga peta daya hantar listrik daerah CAT Sumowono dapat menjadi suatu informasi bagi masyarakat yang menggunakan airtanah dari CAT Sumowono tersebut. Maka dari itu perlu adanya pembuatan peta daya hantar listrik daerah CAT Sumowono agar masyarakat merasa nyaman dan aman dalam memanfaatkan airtanah. Metode interpolasi data DHL menggunakan analisis geostatistik yang terdapat pada perangkat lunak ArcGIS 10.3. Metode interpolasi yang digunakan adalah Inverse Distance Weighting (IDW), Radial Basis Functions (RBF) dan Empirical Bayesian Kriging (EBK). Dari keseluruhan data yang terinterpolasi, didapatkan dua kelas kualitas airtanah berdasarkan nilai DHL, yaitu Sangat Baik $(<250 \mathrm{~S} / \mathrm{cm})$ dan Baik $(250-750 \mathrm{~S} / \mathrm{cm})$. Metode interpolasi yang dinilai paling seimbang adalah metode RBF. Melalui peta DHL hasil interpolasi metode RBF diketahui persebaran daerah dengan kelas sangat baik pada daerah CAT Sumowono mencakup 52,8\% dari luas CAT dan 47,2\% masuk ke dalam kelas baik.
\end{abstract}

Keywords: Cekungan Air Tanah, Sumowono, Daya Hantar Listrik, Geostatistik, Interpolasi

\section{PENDAHULUAN}

Airtanah sebagai salah satu bagian dari sumberdaya air merupakan sumberdaya yang paling diminati oleh manusia. Keberadaan airtanah sangat melimpah serta kualitas yang baik menjadi salah satu faktor tingginya minat manusia menjadikan airtanah menjadi salah satu sumber air bersih (Yudistira \& Adji, 2014). Dan sebagai sumber air yang paling diminati, perlu cermat untuk melakukan pengelolaan dan pemanfaatan airtanah.

Kualitas airtanah terdiri dari fisik, kimia, dan kualitas biologis air tanah. Suhu, kekeruhan, warna, rasa, dan bau termasuk dalam parameter fisik kualitas airtanah. Karena sebagian besar airtanah tidak berwarna, tidak berbau, dan tanpa rasa tertentu, masyarakat biasanya paling khawatir dengan kualitas kimia dan biologi (Harter, 2003).

Daya Hantar Listrik (DHL atau electric conductance) adalah sifat menghantarkan listrik air. Air yang banyak mengandung garam akan mempunyai $\mathrm{DHL}$ tinggi. Pengukurannya dengan alat Electric Conductance Meter (EC Meter), yang satuannya adalah mikro mhos/cm atau $\mu \mathrm{mhos} / \mathrm{cm}$ atau sering ditulis umhos. Semakin tinggi air mencerminkan kualitas airtanah yang buruk (Danaryanto dkk., 2008).

ArcGIS adalah perangkat yang sangat populer dan andal dalam melakukan tugas-tugas Sistem Informasi Geografis (GIS). Meskipun cukup banyak perangkat lunak alternatif yang lebih murah dan bahkan gratis, tetapi ArcGIS masih menjadi perangkat lunak GIS yang utama. Keandalan ArcGIS tidak saja dalam hal membuat peta, melainkan yang lebih utama adalah membantu praktisi SIG melakukan analisis, pemodelan, dan pengelolaan data spasial secara efektif dan efisien (Raharjo dan Ikhsan, 2015).

Oleh karena itu dibutuhkan suatu informasi mengenai daerah yang memiliki nilai $\mathrm{DHL}$ yang tinggi atau rendah beserta nilainya pada tiap titik lokasi sebagai pengetahuan masyarakat mengenai kualitas airtanah yang digunakannya dalam sehari-hari yang dibuat dengan bantuan perangkat lunak ArcGIS 10.3 .

Tujuan dari penelitian ini adalah untuk mengetahui tahapan dalam pembuatan peta $\mathrm{DHL}$, memahami macam 
metode yang dapat digunakan untuk interpolasi data dan mengetahui kualitas air tanah pada CAT Sumowono dari nilai DHL. Penelitian diharapkan dapat menjadi bahan acuan bagi Pemerintah Kabupaten Semarang, Temanggung dan Kendal dalam mengelola kualitas airtanah CAT Sumowono.

\section{METODOLOGI Lokasi Penelitian}

Secara

geografis daerah penyelidikan terletak di antara garis 9197102-9215728 m (Utara) dan 396658$426897 \mathrm{~m}$ (Timur), meliputi Kabupaten Kendal, Kabupaten Temanggung, dan Kabupaten Semarang (Gambar 1).

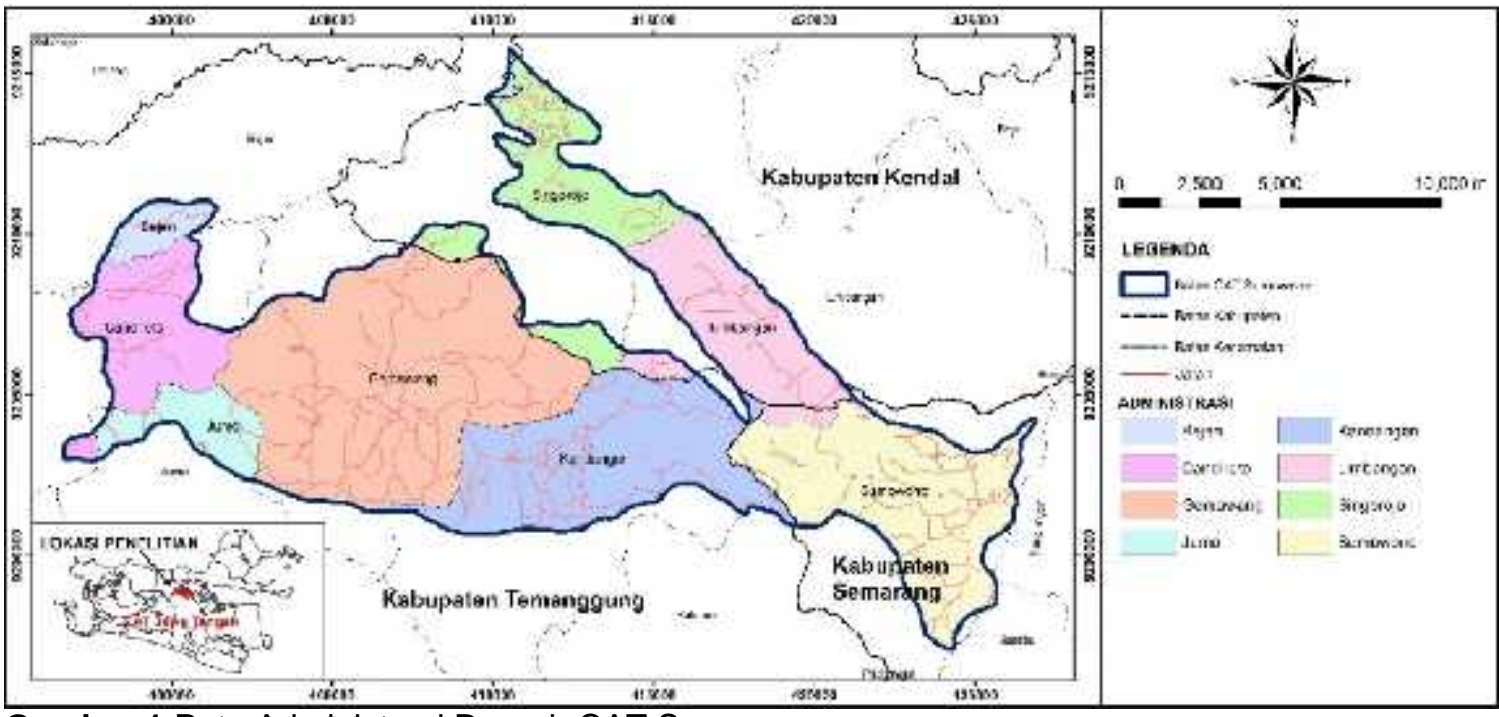

Gambar 1 Peta Administrasi Daerah CAT Sumowono

\section{Peralatan}

Berbagai macam penyelidikan dilakukan untuk memenuhi data-data yang diperlukan dalam menunjang penelitian ini. Data tersebut diperoleh dengan menggunakan berbagai macam alat baik untuk pekerjaan lapangan maupun analisis laboratorium, antara lain:

1. GPS (Global Positioning System).

2. Electric conductivity/EC-meter untuk mengukur DHL air tanah.

3. Water level indicator untuk mengukur muka airtanah dari muka tanah.

4. pH-meter untuk mengukur derajat keasaman air.

5. Thermometer untuk mengukur suhu air.

6. Kompas dan palu geologi yang terutama digunakan untuk pengamatan/ pengukuran singkapan batuan.

7. Stopwatch untuk pengukuran waktu dalam pekerjaan uji debit Mata air.

8. Kamera untuk dokumentasi kegiatan lapangan.

9. Komputer dan perangkat lunak (software) untuk analisis data, penulisan laporan, serta penggambaran peta-peta.

\section{Lingkup Penyelidikan}

Lingkup kegiatan penyelidikan pembuatan Peta DHL Cekungan Airtanah (CAT) Sumowono meliputi beberapa hal sebagai berikut:
1. Pengumpulan data sekunder yang berkaitan dengan kondisi dan lingkungan airtanah di lokasi penyelidikan.

2. Pengukuran pengukuran $\mathrm{DHL}$, analisis fisika airtanah di lapangan dari sumur gali dan Mata air terpilih serta pengambilan percontoh airtanah.

3. Analisis fisika percontoh airtanah di laboratorium.

4. Evaluasi dan analisis data terkumpul di lapangan dan di kantor.

5. Penyajian hasil penyelidikan secara lengkap dalam bentuk laporan yang dilengkapi dengan peta, gambar, foto, dan tabel serta sajian data berikut analisisnya.

\section{HASIL DAN PEMBAHASAN \\ Titik Minatan Air tanah}

Pemunculan mata air pada CAT Sumowono sangat banyak ditemukan. Bahkan hampir setiap desa terdapat titik mata air yang keluar dengan debit yang beragam. Mata air yang terdapat CAT Sumowono ini umumnya muncul pada daerah tekukan lereng atau daerah rendahan. Mata air tersebut digunakan untuk berbagai macam keperluan, seperti pengairan untuk sawah-sawah masyarakat hingga sumber air bersih utama maupun budidaya perikanan air tawar. Di beberapa 
tempat Mata air tersebut dialirkan hingga ke pemukiman melalui saluran pipa-pipa setempat. Bahkan PDAM Kabupaten Temanggung, Kabupaten Kendal dan Kabupatan Semarang hanya menggunakan titik Mata air yang berupa PAMSIMAS untuk mengalirkan air bersih kepada masyarakat, hal ini menunjukan bahwa potensi airtanah dangkal daerah CAT Sumowono masih sangat besar. Namun terdapat juga Mata air yang belum dimanfaatkan atau hanya dibiarkan karena letaknya yang sulit dijangkau sehingga pipa atau alat lainnya tidak mampu mencapai ke titik Mata air tersebut, seperti pada titik minatan nomor 15 yaitu Mata air (MA 15) Sidoharojo, Desa Sidoharjo, Kecamatan Candiroto dimana Mata air tersebut keluar pada pinggir sungai dan terdapat longsoran-longsoran yang menutupi keluarnya mata air tersebut, sehingga sulit untuk menjangkau titik karena letaknya yang berada didaerah rendahan.

Sebaran titik Mata air ini terdapat hampir di seluruh daerah CAT namun keberadaannya mulai jarang ditemui di bagian barat CAT Sumowono, daerah barat CAT Sumowono mulai banyak ditemui sumur-sumur gali yang digunakan masyarakat untuk menjadi sumber air bersih selain menggunakan Mata air (Gambar 2).

Total keseluruhan titik Mata air yang dapat ditemukan di daerah penelitian adalah sebanyak 69 titik dengan debit yang beragam, sedangkan total keseluruhan titik sumur gali yang dapat ditemukan di daerah penelitian adalah sebanyak 46 titik. Dengan demikian, total keseluruhan titik minatan airtanah pada penelitian ini adalah sebanyak 115 titik minatan.

\section{Daya Hantar Listrik}

Dari hasil pengukuran DHL di lapangan terhadap 115 sampel airtanah berkisar antara 36-550 S/cm (lampiran 1). Beberapa contoh pengukuran menunjukkan nilai $\mathrm{DHL}$ yang lebih tinggi dari Mata air yang lain yaitu titik minatan di Sidoharjo (SD 9), Sucen (SD 29), Muncar (SD 48) dan Karangseneng (MA 62) dengan nilai antara 386-550 S/cm.

Sesuai dengan tabel klasifikasi air berdasarkan daya hantar listrik pada tabel 1, maka contoh air dari seluruh titik minatan termasuk ke dalam kualitas sangat baik-baik, karena nilai DHL masih di bawah $1.000 \mathrm{~S} / \mathrm{cm}$. Apabila dilihat dari nilai DHL, keseluruhan titik minatan pada daerah penelitian termasuk dalam kriteria layak minum sesuai dengan standar baku air minum dalam PERMENKES NO. 492/MENKES/PER/ IV/2010.

Tabel 1 Klasifikasi air berdasarkan daya hantar listrik (Sen, 2015)

\begin{tabular}{ll}
\hline $\begin{array}{l}\text { Daya hantar listrik } \\
(\boldsymbol{\mu S} / \mathbf{c m})\end{array}$ & Kualitas Air \\
\hline$<250$ & Sangat Baik \\
$250-750$ & Baik \\
$750-2.000$ & Sedang \\
$2.000-3.000$ & Buruk \\
$\geq 3.000$ & Sangat Buruk \\
\hline
\end{tabular}

Interpolasi Menggunakan Geostatistical Analyst

Pembuatan interpolasi data DHL digunakan 3 metode geostatistik yang terdapat di aplikasi ArcGIS yaitu:

\section{Inverse Distance Weighting (IDW)}

Metode inverse distance weighting (Gambar 3) menitik beratkan pada fungsi power, sehingga metode ini memiliki kecenderungan untuk membentuk hasil yang berupa bulls eye pada daerah-daerah yang memiliki nilai $\mathrm{DHL}$ yang tinggi. Pada bagian Power pada properties, dilakukan automatic input power value yang merupakan menu otomatis untuk mendapatkan nilai power yang paling sesuai dengan data yang senilai dengan 1,2 . 


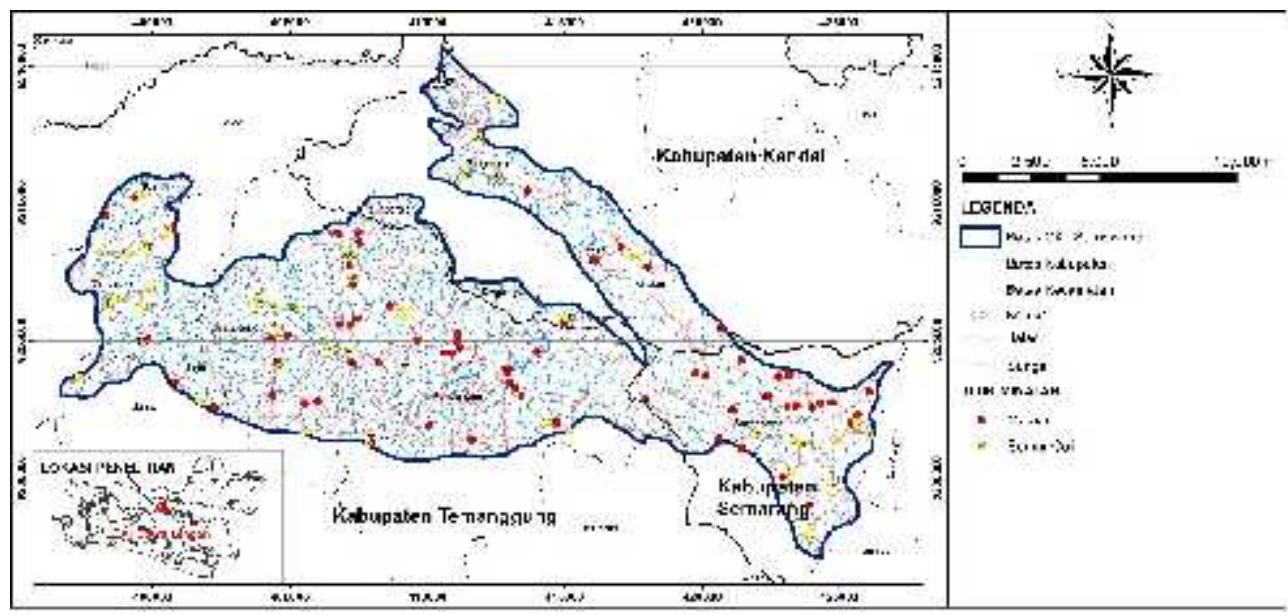

Gambar 2 Peta Titik Minatan Daerah CAT Sumowono

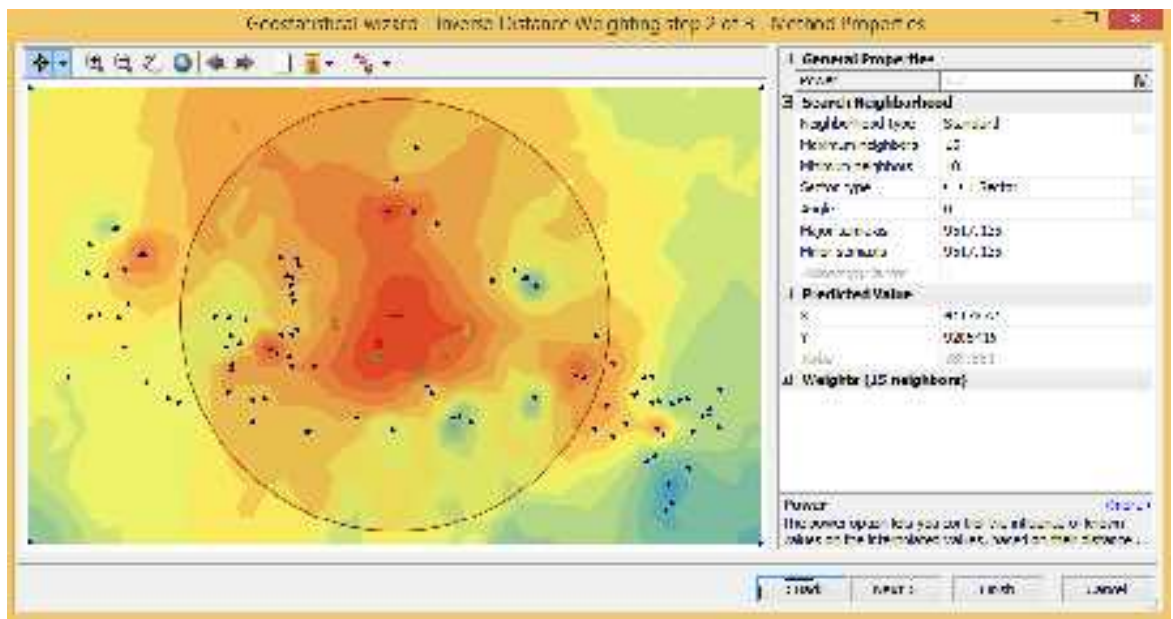

Gambar 3 Pengaturan metode IDW

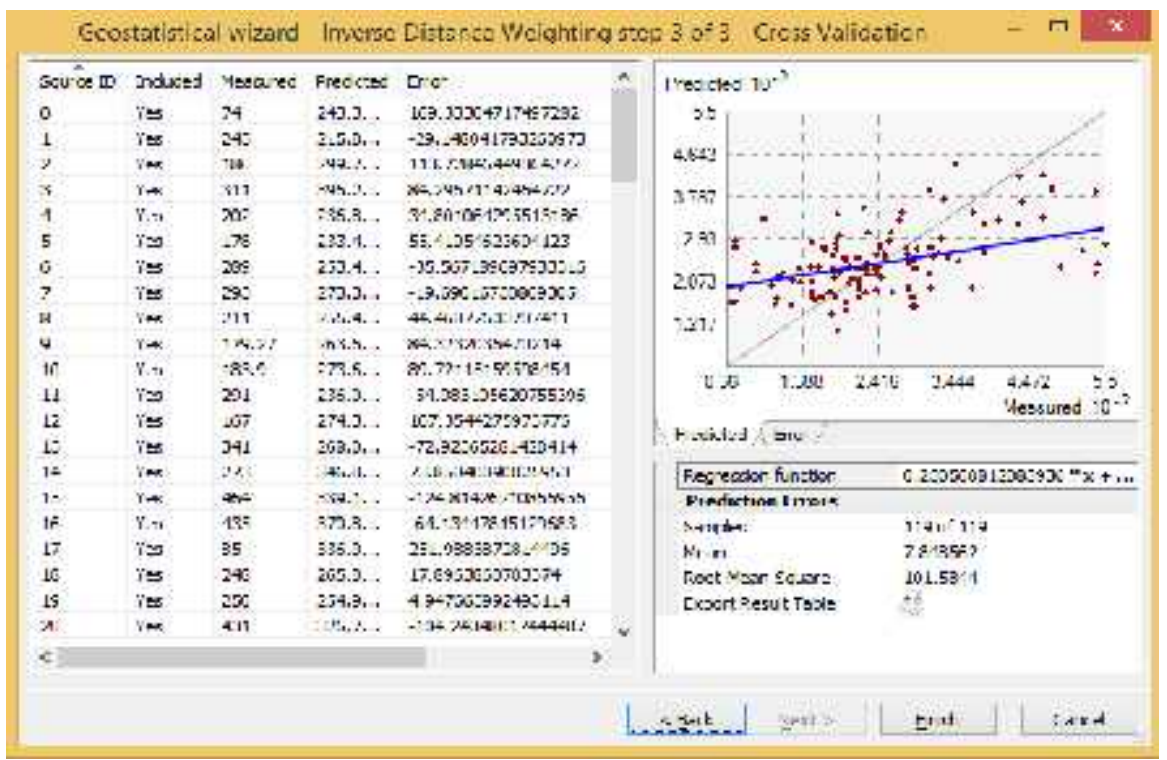

Gambar 4 Cross Validation IDW

Root-Mean-Square/RMS merupakan nilai yang dapat digunakan untuk menilai akurasi dari interpolasi data. Semakin kecil nilai RMS, maka interpolasi memiliki akurasi yang semakin baik. Berdasarkan data yang sudah di interpolasikan, maka didapatkan nilai RMS sebesar $102 \mathrm{~S} / \mathrm{cm}$ (Gambar 4).

2. Radial Basis Functions (RBF) 
Metode Radial Basis Functions (Gambar 5) merupakan fungsi yang menggunakan pendekatan jarak, sehingga data di suatu titik yang belum diketahui sebelumnya dapat ditafsirkan nilainya sesuai fungsi pendekatan jarak. Pada bagian Kernel Parameter digunakan nilai 0,2 karena dengan nilai tersebut menghasilkan RMS yang lebih kecil dan mengindikasikan interpolasi yang semakin baik dan akurat.

Berdasarkan data yang sudah di interpolasikan menggunakan metode RBF, maka didapatkan nilai RMS sebesar 101 S/cm (Gambar 6).

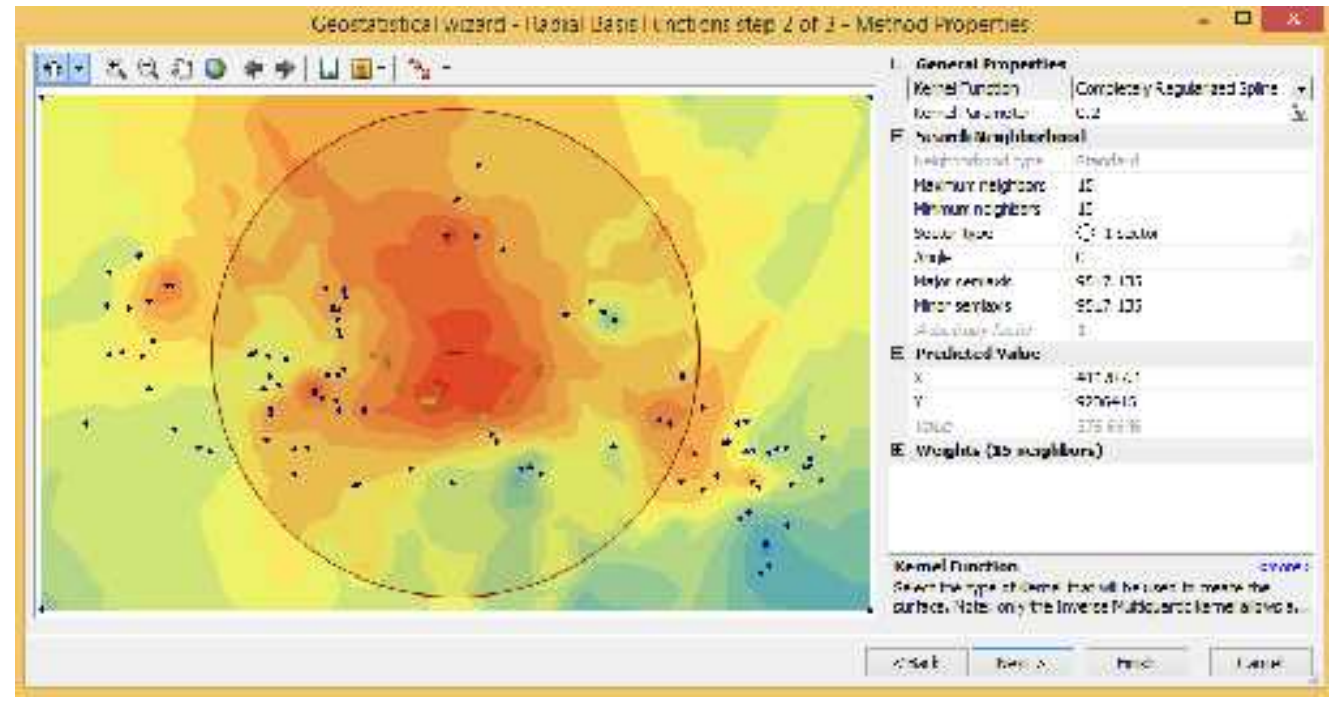

Gambar 5 Pengaturan metode RBF

\section{Empirical Bayesian Kriging (EBK)}

Empirical Bayesian Kriging (EBK) adalah metode interpolasi geostatistik yang mengatur secara otomatis aspek untuk membangun sebuah model kriging (Gambar 7). Pada metode kriging di Geostatistic Analyst mengharuskan untuk menyesuaikan parameter secara manual untuk menerima hasil yang akurat, namun EBK dapat menghitung otomatis parameter tersebut melalui proses subsetting dan simulasi. Kelebihan dari EBK terdapat pada bagian perhitungan kesalahan, dimana EBK memperkirakan semivariogram dengan standar prediksi, berbeda dengan metode kriging lainnya yang tidak mengambil kepastian estimasi semivariogram dan tidak mengacu pada standar prediksi.

Berdasarkan data yang sudah di interpolasikan menggunakan metode EBK, maka didapatkan nilai RMS sebesar 98,9 S/cm (Gambar 8).

Pembahasan Peta Daya Hantar Listrik

Metode interpolasi IDW, RBF dan EBK merupakan metode yang digunakan dalam interpolasi data DHL untuk membuat peta DHL. Setiap metode memiliki fungsi yang berbeda dalam interpolasi sehingga hasil yang diterima juga memiliki perbedaan seperti yang tercantum pada Tabel 2 .

Tabel 2 Matriks Peta DHL

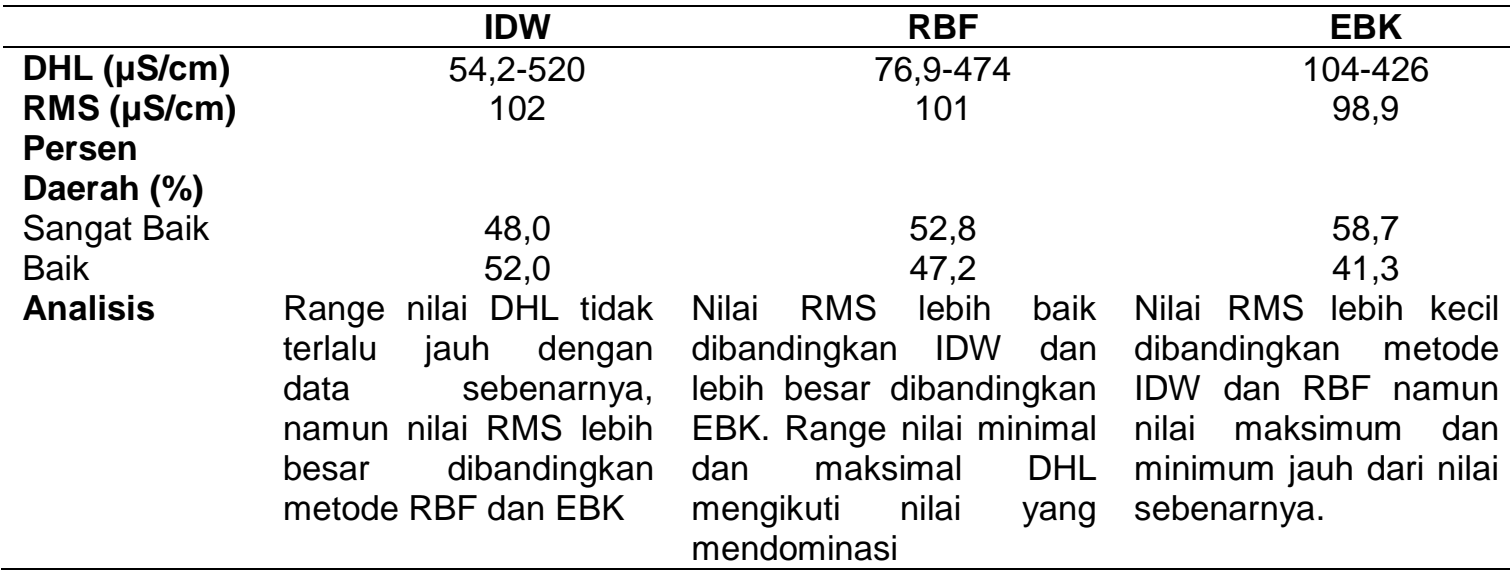




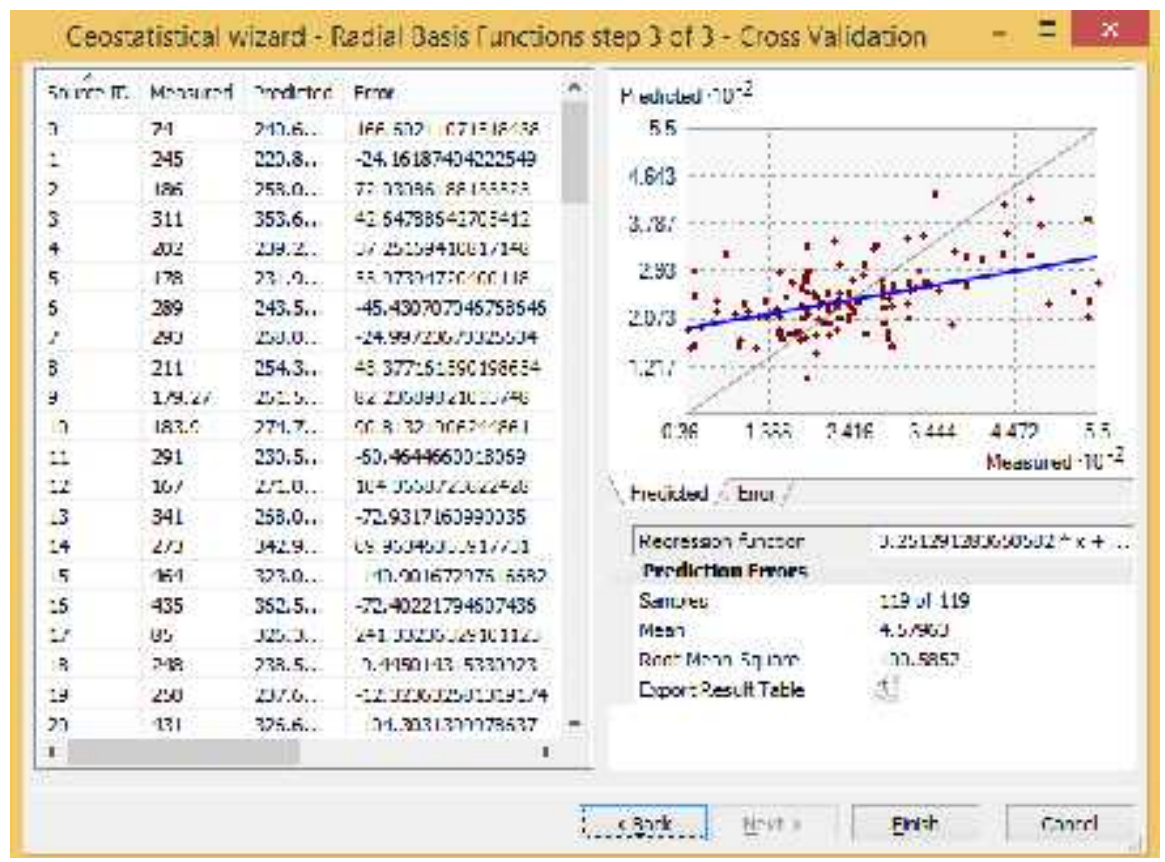

\section{Gambar 6 Cross validation RBF}

Secara keseluruhan, ketiga metode interpolasi yang digunakan menghasilkan peta $\mathrm{DHL}$ yang tidak jauh berbeda. Apabila dilihat dari parameter RMS, maka metode yang paling baik adalah metode EBK. Namun EBK memiliki kekurangan dimana interpolasi yang dilakukan metode EBK membuat data minimal dan maksimal sebenarnya yaitu 36-550 S/cm menjadi hilang karena nilai tersebut tidak dominan. Penghilangan data maksimal dan minimal ini menjadi suatu masalah karena menyebabkan hilangnya kewaspadaan pada daerah yang sebenarnya memiliki nilai DHL $550 \mathrm{~S} / \mathrm{cm}$ namun dianggap lebih kecil dari nilai tersebut akibat dari proses interpolasi. Hal serupa juga terjadi pada daerah yang memiliki nilai DHL $36 \mathrm{~S} / \mathrm{cm}$ dan berpotensi baik, menjadi tidak dapat diidentifikasi lagi karena tidak dominan dan berubah menjadi lebih besar mengikuti data di sekelilingnya. Pada hasil peta $\mathrm{DHL}$ metode EBK, $58,7 \%$ daerah CAT Sumowono memiliki airtanah dengan $\mathrm{DHL}$ yang sangat baik dan $41,3 \%$ daerah lainnya baik (Gambar 9).

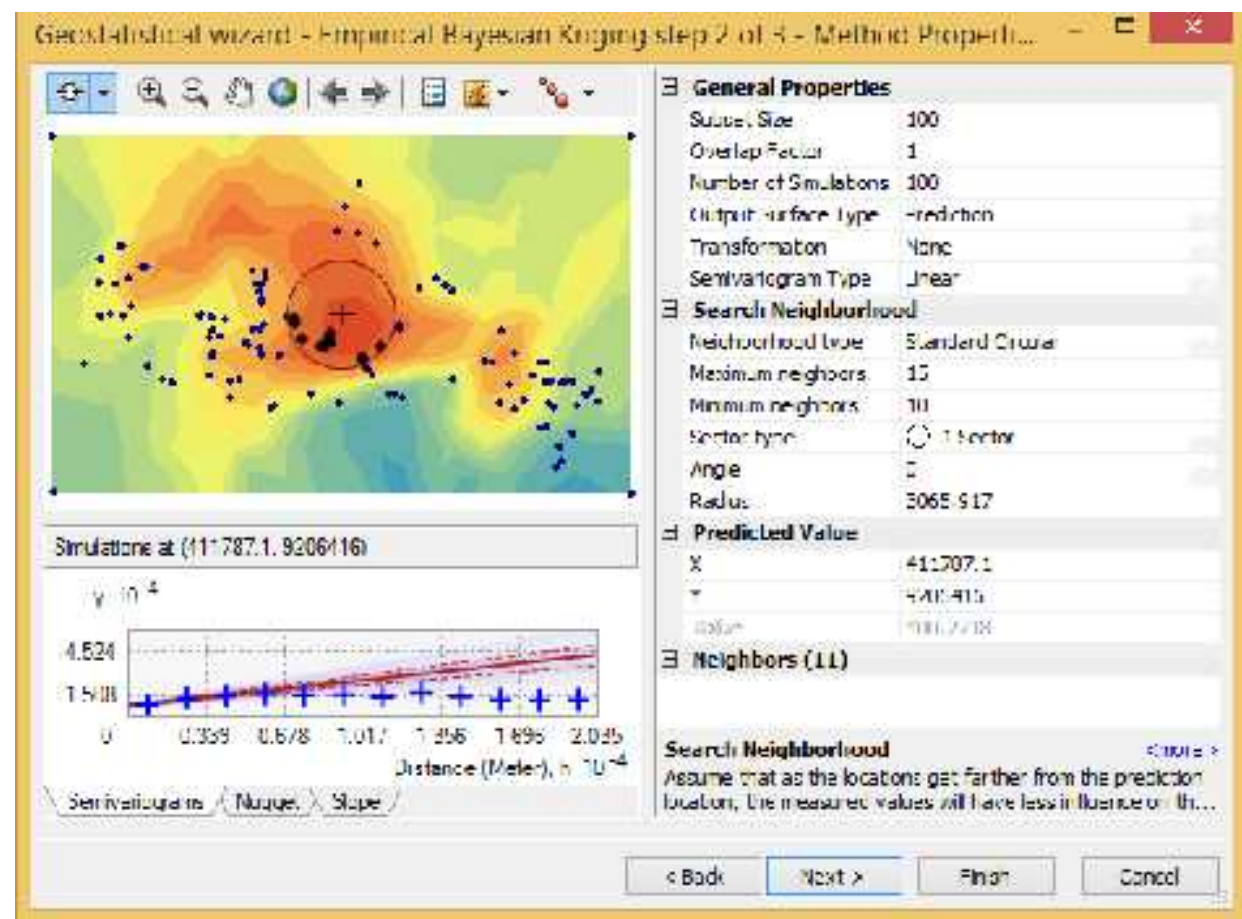

Gambar 7 Properti EBK 
Metode IDW merupakan metode yang memiliki range nilai $\mathrm{DHL}$ terdekat dengan nilai sebenarnya, akan tetapi metode ini memiliki nilai RMS terbesar dibandingkan metode RBF dan EBK, sehingga akurasi dari ketiga metode dinilai paling lemah. Pada hasil peta DHL metode IDW, 48\% daerah CAT Sumowono memiliki airtanah dengan DHL yang sangat baik dan $52 \%$ daerah lainnya baik (Gambar 10 ).

Metode RBF merupakan metode yang menggunakan fungsi pendekatan jarak dalam interpolasi. Nilai RMS dari RBF berada diantara RMS dari metode IDW dan EBK. Kemudian dari hasil interpolasi, diketahui bahwa range nilai yang didapatkan memang mengikuti nilai yang mendominasi, sehingga nilai yang yang tidak dominan dihilangkan. Akan tetapi range nilai RBF lebih dekat dengan nilai sebenarnya dibandingkan hasil dari metode EBK.

Pada hasil peta DHL metode RBF $52,8 \%$ daerah CAT Sumowono memiliki airtanah dengan $\mathrm{DHL}$ yang sangat baik dan $47,2 \%$ daerah lainnya baik (Gambar 11). Maka dapat diketahui bahwa metode RBF memiliki hasil yang lebih seimbang dibandingkan hasil dari metode lainnya dan dapat digunakan sebagai acuan peta $\mathrm{DHL}$ CAT Sumowono.

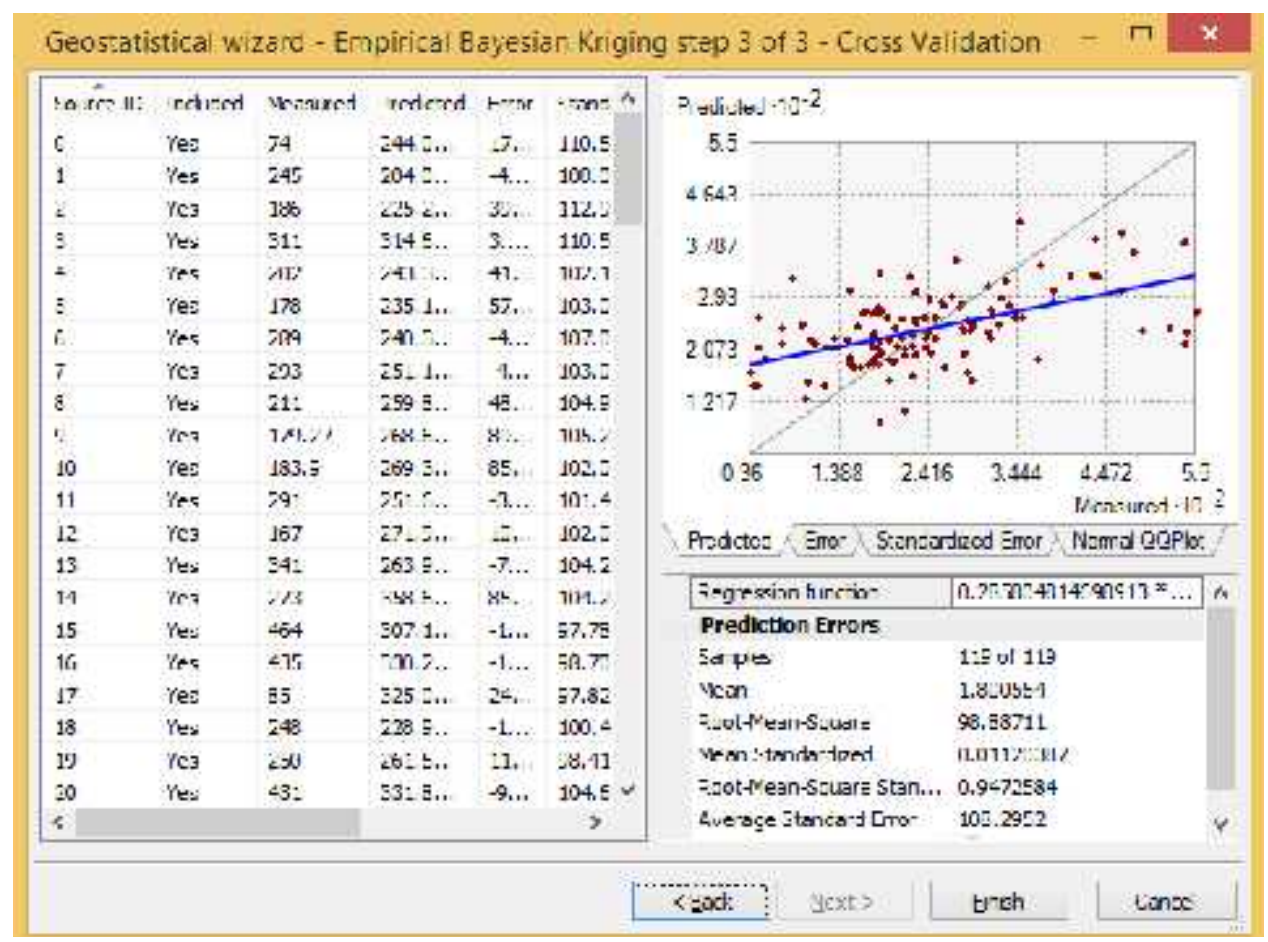

Gambar 8 Cross validation EBK

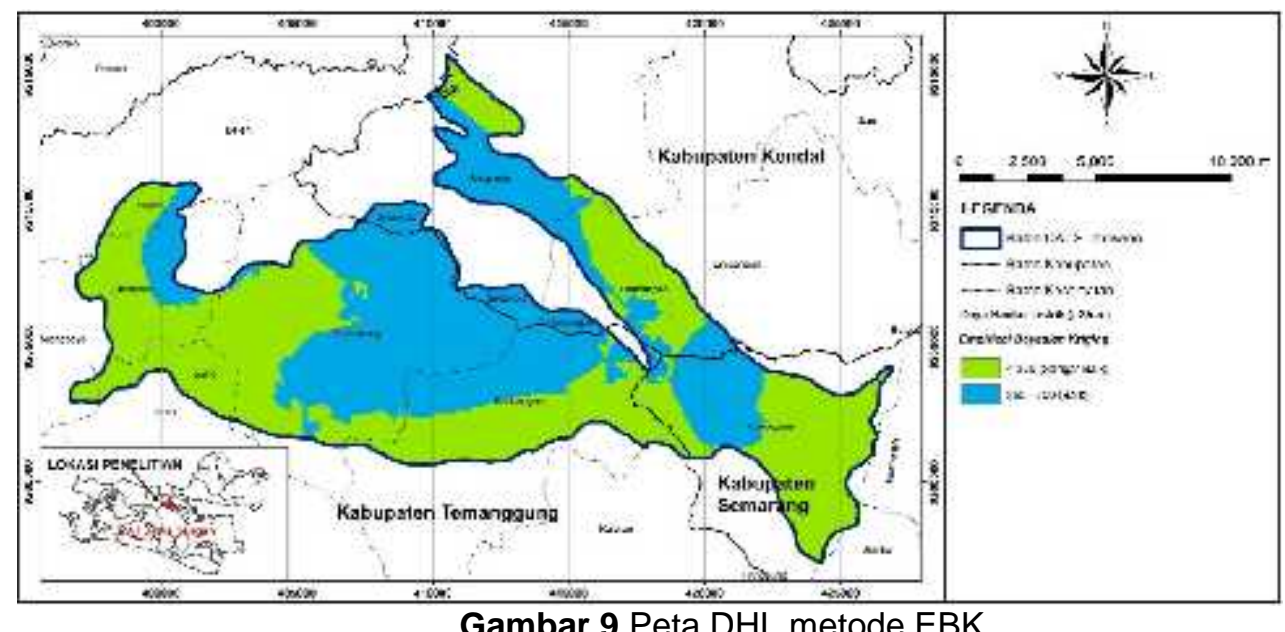

Gambar 9 Peta DHL metode EBK 


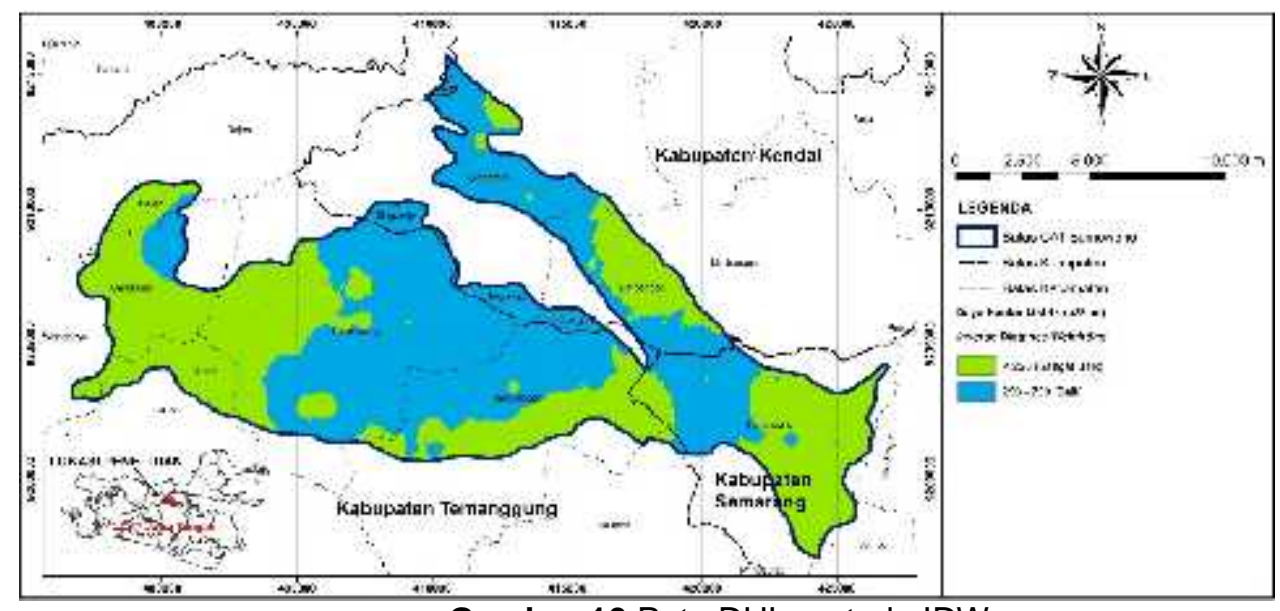

Gambar 10 Peta DHL metode IDW

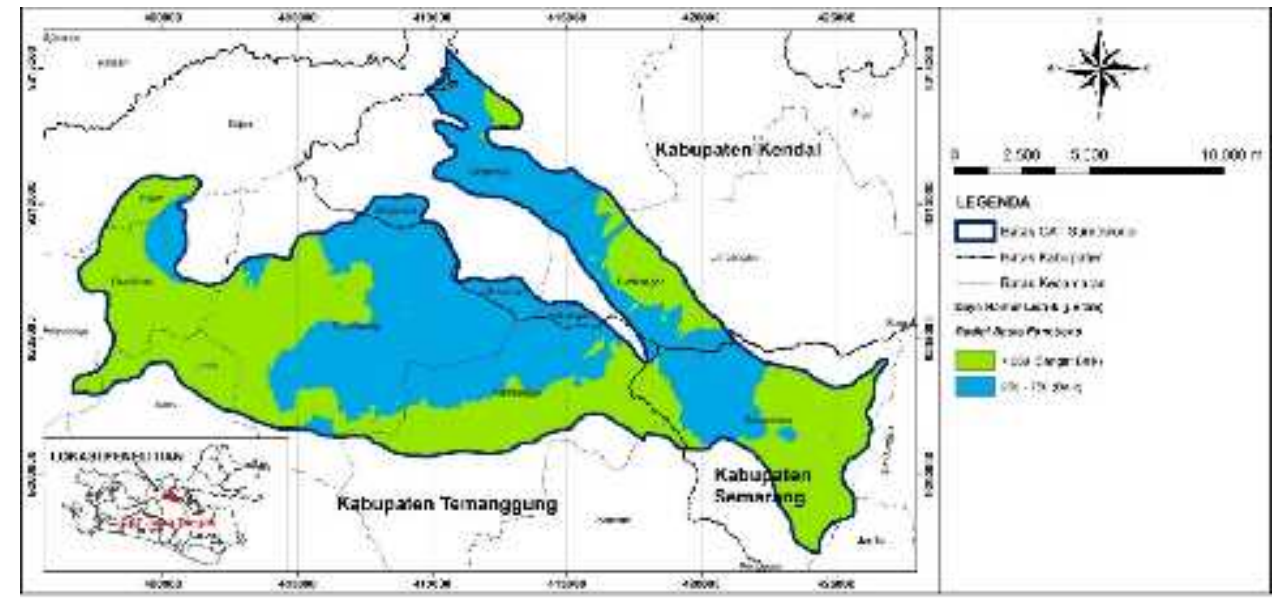

Gambar 11 Peta DHL metode RBF

\section{KESIMPULAN}

Dari pembuatan peta DHL menggunakan perangkat lunak ArcGIS 10.3 pada daerah CAT Sumowono maka dapat didapatkan kesimpulan:

1. Tahapan dalam pembuatan peta $\mathrm{DHL}$ adalah:

a. Pengumpulan data sekunder

b. Pengukuran DHL

c. Analisis fisika percontoh airtanah di laboratorium.

d. Evaluasi dan analisis data terkumpul di lapangan dan di kantor.

e. Penyajian hasil penyelidikan

2. Macam-macam metode interpolasi yang digunakan dalam pembuatan peta $\mathrm{DHL}$ adalah:

a. Inverse Distance Weighting (IDW)

b. Radial Basis Function (RBF)

c. Empirical Bayesian Kriging (EBK)

3. Daerah CAT Sumowono terbagi dalam 2 delineasi kualitas airtanah berdasarkan DHL, yaitu:

a. Sangat Baik $(<250 \quad \mathrm{~S} / \mathrm{cm})$, dengan persebaran daerah:

1. IDW : $48 \%$ dari CAT Sumowono
2. RBF : $52,8 \%$ dari CAT Sumowono

3. EBK : $58,7 \%$ dari CAT Sumowono

b. Baik (250-750 S/cm), dengan persebaran daerah:

1. IDW : $52 \%$ dari CAT Sumowono

2. RBF : $47,2 \%$ dari CAT Sumowono

3. EBK : $41,3 \%$ dari CAT Sumowono

\section{DAFTAR PUSTAKA}

Danaryanto, Kodoatie, R.J.., Satriyo, H., \& Sangkawati, S. (2008). Manajemen Air Tanah Berbasis Konservasi. Direktorat Pembinaan Pengusahaan Panas Bumi dan Pengelolaan Air Tanah, Direktorat Jenderal Mineral, Batubara dan Panas Bumi, Departemen Energi dan Sumber Daya Mineral.

Harter, T. (2003). Basic Concepts of Groundwater. Agriculture and Natural Resources, University of California, 16.

Keputusan Menteri Negara Lingkungan 
Hidup Nomor: 115 Tahun 2003 tentang Pedoman Status Mutu Air.

Permenkes No. 492 Tahun 2010 tentang Persyaratan Kualitas Air Minum.

Raharjo, B. \& Ikhsan, M. (2015). Belajar ArcGIS Desktop 10: ArcGIS 10.2/10.3. Geosiana Press.

Banjarbaru

Se, Z. (2015). Practical and Applied
Hydrogeology. ITU Hydraulic Lab. Maslak, Istambul Turkey. $1^{\text {st }}$ Ed. Elsevier.

Yudistira, A. \& Adji, T. N. (2014). Kajian Potensi dan Arahan Penggunaan Airtanah Untuk Kebutuhan Domestik di Kecamatan Depok Kabupaten Sleman. Universitas Gadjah Mada. 